\title{
Methodiek Schoolverlatersinformatiesysteem 2000
}

\author{
Citation for published version (APA):
}

Potma, L. (2002). Methodiek Schoolverlatersinformatiesysteem 2000. Researchcentrum voor Onderwijs en Arbeidsmarkt, Faculteit der Economische Wetenschappen. ROA Working Papers No. 2 https://doi.org/10.26481/umarow.2002002

Document status and date:

Published: 01/01/2002

DOI:

10.26481/umarow.2002002

Document Version:

Publisher's PDF, also known as Version of record

\section{Please check the document version of this publication:}

- A submitted manuscript is the version of the article upon submission and before peer-review. There can be important differences between the submitted version and the official published version of record.

People interested in the research are advised to contact the author for the final version of the publication, or visit the DOI to the publisher's website.

- The final author version and the galley proof are versions of the publication after peer review.

- The final published version features the final layout of the paper including the volume, issue and page numbers.

Link to publication

\footnotetext{
General rights rights.

- You may freely distribute the URL identifying the publication in the public portal. please follow below link for the End User Agreement:

www.umlib.nl/taverne-license

Take down policy

If you believe that this document breaches copyright please contact us at:

repository@maastrichtuniversity.nl

providing details and we will investigate your claim.
}

Copyright and moral rights for the publications made accessible in the public portal are retained by the authors and/or other copyright owners and it is a condition of accessing publications that users recognise and abide by the legal requirements associated with these

- Users may download and print one copy of any publication from the public portal for the purpose of private study or research.

- You may not further distribute the material or use it for any profit-making activity or commercial gain

If the publication is distributed under the terms of Article $25 \mathrm{fa}$ of the Dutch Copyright Act, indicated by the "Taverne" license above, 
Methodiek Schoolverlatersinformatiesysteem 2000

ROA-W-2002/2

Lia Potma

Researchcentrum voor Onderwijs en Arbeidsmarkt

Faculteit der Economische Wetenschappen en Bedrijfskunde Universiteit Maastricht

Maastricht, maart 2002 
ISBN 90-5321-333-3

Sec02.045.doc 
Inhoud

Bladzijde

Voorwoord

1 Inleiding 1

2 Schoolverlatersonderzoeken 1

3 Dataverwerking en weging 3

4 Dekkingsgraad en respons $\quad 7$

5 Non-respons 13

$6 \quad$ Internet versus schriftelijk 17

7 Besluit 22

Literatuur 23

Appendix A: Kernvragenlijst 25 



\section{Voorwoord}

Dit werkdocument gaat in op de methodiek die in het uitvoeringsjaar 2000 gehanteerd wordt binnen het schoolverlatersonderzoek zoals dat door het ROA wordt uitgevoerd. Het betreft de enquêtes Registratie van Uitstroom en Bestemming van Schoolverlaters (RUBS), HBO-Monitor en WO-Monitor. Deze enquetes zijn sinds 1996 in vergaande mate geïntegreerd in het Schoolverlatersinformatiesysteem (SIS), waardoor een vergelijkbaar systeem ontstaan is met gegevens over schoolverlaters uit vrijwel het gehele secundair en tertiair onderwijs. In het kader van het onderzoek binnen dit informatiesysteem is onder andere het rapport en de statistische bijlage van Schoolverlaters tussen onderwijs en arbeidsmarkt 2000 gepubliceerd. Daarnaast zijn er nog drie specifieke rapportages verschenen, te weten een rapport over de arbeidsmarktpositie van afgestudeerden van het $\mathrm{HBO}$, een rapport over de arbeidsmarktpositie van afgestudeerden van het kunstvakonderwijs en een rapport over afgestudeerden van de lerarenopleidingen.

Het SIS 2000 is financieel mogelijk gemaakt door de Ministeries van Onderwijs, Cultuur en Wetenschappen, Sociale Zaken en Werkgelegenheid en Landbouw, Natuurbeheer en Visserij, het Expertisecentrum voor Loopbaanvraagstukken LDC, de HBO-Raad, de VSNU en de deelnemende onderwijsinstellingen. Bij de uitvoering van het onderzoek is samengewerkt met DESAN Research Solutions te Amsterdam en STOAS Onderzoek te Wageningen. Binnen het ROA is de projectleiding van het SIS in handen van dr. R.K.W. van der Velden en dr. M.H.J. Wolbers. Dit werkdocument is samengesteld door E.J. Potma. Verder hebben aan het SIS 2000 meegewerkt: dr. J.P. Allen, drs. T.G. Huijgen, P.J.E.G. van der Kolk, drs. G.W.M. Ramaekers, E.M.H.P. Soudant en dr. H.F. Vaatstra (allen werkzaam bij ROA), alsmede drs. M. C.M.Th. van Alphen, drs. H. van Dongen en drs. R. Tjemmes (allen werkzaam bij DESAN Research Solutions). 



\section{Inleiding}

Door het ROA worden jaarlijks drie grootschalige schoolverlatersonderzoeken uitgevoerd. In de eerste plaats betreft dit een onderzoek onder de schoolverlaters van het algemeen voortgezet onderwijs (AVO), het voorbereidend beroepsonderwijs (VBO $)^{1}$, de beroepsopleidende leerweg $(B O L)$ en de beroepsbegeleidende leerweg (BBL) van het secundair beroepsonderwijs aan de hand van de enquête Registratie van Uitstroom en Bestemming van Schoolverlaters (RUBS). In de tweede plaats is dit een onderzoek onder de afgestudeerden van het Hoger Beroepsonderwijs (HBO) via de HBO-Monitor. In de derde plaats wordt onderzoek verricht onder de afgestudeerden van de universiteiten (WO-Monitor). Deze schoolverlatersonderzoeken tesamen vormen de basis voor een aantal landelijke publicaties, zoals het rapport en de statistische bijlage Schoolverlaters tussen onderwijs en arbeidsmarkt 2000 en de rapporten De arbeidsmarktpositie van afgestudeerden van het hoger beroepsonderwijs; HBO-Monitor 2000, De arbeidsmarktpositie van afgestudeerden van het Kunstenonderwijs; Kunsten-Monitor 2000 en $\mathrm{Na}(\mathrm{ar})$ de lerarenopleiding; Onderwijsmonitor 2000.

Dit werkdocument vormt een methodologische aanvulling op de reeds verschenen en nog te verschijnen rapporten. Er zal met name worden ingegaan op de gehanteerde methodiek, de respons en het uitgevoerde non-responsonderzoek. De opzet van dit werkdocument is als volgt. Allereerst wordt in paragraaf 2 een uiteenzetting gegeven over het doel en de opzet van de schoolverlatersonderzoeken. In paragraaf 3 wordt ingegaan op de dataverwerking en de weging van de gegevens. Vervolgens wordt in paragraaf 4 een overzicht gegeven van de dekkingsgraad en de respons. Paragraaf 5 bevat een verslag van het non-responsonderzoek. In paragraaf 6 wordt dieper ingegaan op eventuele verschillen tussen afgestudeerden die de vragenlijst schriftelijk dan wel via internet hebben ingevuld. Ten slotte worden in paragraaf $7 \mathrm{de}$ belangrijkste conclusies van dit werkdocument kort samengevat.

\section{Schoolverlatersonderzoeken}

Doel

De schoolverlatersenquêtes van het ROA zijn gericht op het monitoren en analyseren van de bestemming van (gediplomeerde) schoolverlaters in het vervolgonderwijs en op de arbeidsmarkt. Daarbij kunnen twee componenten worden onderscheiden: een toepassingscomponent en een onderzoekscomponent. De toepassingscomponent richt zich op de zorg van individuele onderwijsinstellingen voor de onderwijskwaliteit en de afstemming van het onderwijs op de behoeften van de arbeidsmarkt. Daarvoor worden zogenaamde instellingsrapportages opgesteld waarin de onderwijsinstellingen informatie krijgen over hun eigen afgestudeerden, waar relevant afgezet tegen het landelijke beeld. Hiermee kunnen management, studierichtingsleiders en decanaat een indruk krijgen van het externe rendement van hun opleidingen.

1. Inclusief het individueel voorbereidend beroepsonderwijs (IVBO). 
De onderzoekscomponent van het schoolverlatersonderzoek, aangeduid als het Schoolverlatersinformatiesysteem (SIS), heeft als doel het analyseren van het doorstroompatroon van schoolverlaters naar vervolgonderwijs en het transitieproces van school naar werk. De resultaten hiervan worden onder meer gepubliceerd via algemeen toegankelijke landelijke rapportages. Hierin ligt het accent op (ontwikkelingen in) het intredeproces van schoolverlaters, de kansen op het vinden van werk, de kwaliteit van het werk en het keuzegedrag van schoolverlaters ten aanzien van mogelijke vervolgopleidingen en de kwaliteit van de aansluiting die daarbij wordt ondervonden.

\section{Opzet}

Zoals is aangegeven vormt een drietal schoolverlatersonderzoeken (RUBS, HBO-Monitor en WO-Monitor) de basis van het SIS. Voor al deze schoolverlatersonderzoeken geldt dat onderwijsinstellingen zelf aangeven of zij met (een deel van) hun schoolverlaters of afgestudeerden willen deelnemen. De RUBS-enquête wordt bij de scholen aangeboden onder verantwoordelijkheid van het ROA. De HBO-Monitor en de Kunstenmonitor worden bij de hogescholen aangeboden onder auspiciën van de HBO-Raad. De WO-Monitor vindt in VSNU-verband plaats. Het ROA draagt zorg voor de uitvoering van de WO-Monitor voor tien universiteiten en heeft daarnaast de landelijke coördinatie. De Rijksuniversiteit Groningen, de Katholieke Universiteit Nijmegen en de Universiteit Twente hebben de enquête zelf uitgevoerd. Ook de gegevens van deze 'lokale' uitvoerders zijn opgenomen in SIS. Binnen het agrarisch onderwijs worden de resultaten van de onderzoeken aangeboden door STOAS Onderzoek te Wageningen.

Door bovengenoemde werkwijze is er niet perse sprake van een aselecte steekproef. Met name bij de RUBS-enquête is de dekkingsgraad niet altijd even hoog (zie paragraaf 4). Mochten er 'witte vlekken' in de deelname aan RUBS ontstaan - zowel naar opleidingsrichting als regio dan wordt hier een aanvullende steekproef getrokken. In 2000 was een aanvullende steekproef echter niet nodig.

Sinds het uitvoeringsjaar 1996 wordt het schoolverlatersonderzoek van het ROA uitgevoerd volgens een geïntegreerd model, waarbij één meetmoment en één kernvragenlijst wordt onderscheiden. In de periode september-december 2000 zijn ongeveer 90.000 schoolverlaters en afgestudeerden van het school-/studiejaar 1998/1999 benaderd met een schriftelijke vragenlijst. Dezelfde vragenlijst werd ook voor een aantal opleidingen via internet beschikbaar gesteld, zodat de schoolverlaters konden kiezen op welke manier ze de vragenlijst wilden invullen (zie ook paragraaf 6). Wanneer schoolverlaters na ruim een maand de vragenlijst nog niet hebben ingevuld, wordt een rappel verstuurd.

Hoewel de vragenlijsten in de kern gelijk zijn, is ook in het uitvoeringsjaar 2000 enige variatie aan vragen tussen de verschillende vragenlijsten. Hiermee wordt recht gedaan aan de verschillen die ertussen de diverse onderwijsniveaus of -sectoren bestaan.

Binnen RUBS zijn aparte lijsten gebruikt voor de schoolverlaters van MAVO/HAVO/VWO, (I)VBO en MBO. Bovendien zijn voor het agrarisch onderwijs op zowel (I)VBO-als MBO-niveau specifieke vragenlijsten gebruikt. Binnen de HBO-Monitor is een aparte vragenlijst opgesteld 
voor de afgestudeerden van het landbouwonderwijs en het pedagogisch onderwijs. Daarnaast is onder de naam Kunsten-Monitor een specifieke vragenlijst opgesteld voor afgestudeerden van HBO Beeldende Kunst en Vormgeving en HBO Muziek en Theater. In het kader van de WOMonitor zijn er, naast de standaard WO-vragenlijst, aparte vragenlijsten opgesteld voor het pedagogisch onderwijs en het agrarisch onderwijs (afgestudeerden van de Landbouw Universiteit Wageningen).

Om een hogere respons te bereiken, is onder HBO-afgestudeerden van het kunstonderwijs die de schriftelijke vragenlijst niet hebben teruggestuurd een deel van de vragenlijst alsnog telefonisch afgenomen. De afgestudeerden van het pedagogisch onderwijs, op HBO en WOniveau, die in eerste instantie niet hebben gereageerd op de schriftelijke enquête, zijn eveneens naderhand telefonisch benaderd.

De vragenlijsten van het uitvoeringsjaar 2000 bestaan uit een viertal hoofdonderwerpen: algemeen (geslacht, leeftijd e.d.), onderwijsloopbaan, arbeidsmarktintrede en een thematisch gedeelte $^{2}$. Binnen de vragenlijsten voor het AVO en het (I)VBO ligt de nadruk op de doorstroom naar het vervolgonderwijs en de redenen van eventuele voortijdige uitval. Tevens wordt in deze vragenlijsten uitgebreid stilgestaan bij de rol van studie- en beroepskeuzebegeleiding. Er wordt slechts in beperkte mate aandacht besteed aan de arbeidsmarktintrede van deze groep schoolverlaters. In de overige vragenlijsten ligt de nadruk juist op het transitieproces van school naar werk en wordt minder vergaand gevraagd over de doorstroom naar vervolgonderwijs.

\section{Dataverwerking en weging}

Het versturen van alle vragenlijsten, het beschikbaar stellen van de vragenlijsten op internet, het verzorgen van de rappels en de verwerking van de binnengekomen vragenlijsten wordt uitgevoerd door DESAN Research Solutions te Amsterdam. Bij de verwerking worden de vragenlijsten ingevoerd of gescand, de open vragen gecodeerd (waaronder vervolgopleiding, beroep, bedrijfssector) en de eerste bestandscontroles en correcties uitgevoerd. Het ROA voert daarna een datacleaning uit op verwijzingsstructuur en op onderlinge consistenties. Vervolgens worden nieuwe samengestelde variabelen aangemaakt en wordt het bestand gewogen, zodat op basis van de gegevens landelijk representatieve uitspraken gedaan kunnen worden.

\section{Dataverwerking}

De vragenlijsten bevatten voor het merendeel gesloten antwoordcategorieën, waarbij de respondenten kunnen kiezen uit een aantal voorgelegde mogelijkheden. In een beperkt aantal gevallen dienen de schoolverlaters zelf een numerieke waarde in te vullen, bijvoorbeeld bij leeftijd, inkomen en aantal gewerkte uren. Bij enkele andere vragen wordt gebruik gemaakt van een volledig open vraagstelling, waarbij de schoolverlaters zelf het antwoord op de vraag moeten omschrijven. Dit is met name het geval bij vragen over:

- soort opleiding (voor- of vervolgopleiding);

2. Zie bijlage A voor een overzicht van het kerndeel van de vragenlijst. 
- beroep;

- bedrijfssector;

- gemeente (woon- of werkgemeente).

Bij deze vragen worden de alfanumerieke antwoorden van de respondenten gecodeerd volgens vooraf opgestelde classificaties. Voor de opleidingsvragen wordt daarbij gebruik gemaakt van een speciaal voor dit doel door het ROA opgestelde opleidingsclassificatie, waarin alle in Nederland voorkomende (reguliere) opleidingen zijn opgenomen ${ }^{3}$. Beroep en bedrijfssector worden gecodeerd volgens de Standaard Beroepen Classificatie 1992 (SBC '92) en de Standaard Bedrijfsindeling 1993 (SBI '93) van het CBS. Overigens zijn beide classificaties, waar relevant, door het toevoegen van een extra digit verder verbijzonderd. Gemeenten worden gecodeerd volgens de gemeentecodes die door het CBS in het meest recente Plaatsnamenregister worden gehanteerd.

$\mathrm{Na}$ de data-entry of het scannen van de vragenlijsten worden de aldus verkregen ruwe gegevens door DESAN onderworpen aan een eerste kwaliteitscontrole. DESAN stelt het onderzoeksbestand samen en controleert op cruciale variabelen zoals uniek casenummer, schoolnummer, opleiding, respons, voltijd/deeltijd opleiding en diplomabezit. Deze variabelen worden onderling en met de variabele 'vragenlijst' op elkaar afgestemd. Bijvoorbeeld: komt een bepaalde (vol- of deeltijd) opleiding voor op een school, is voor een opleiding de juiste vragenlijst gehanteerd, is de vragenlijst grotendeels (naar waarheid) ingevuld, zijn de afgestudeerden ook gediplomeerd e.d. $\mathrm{Na}$ deze eerste controle geeft DESAN het onderzoeksbestand aan het ROA, waar vervolgens de volgende controles en correcties uitgevoerd worden:

1. Controle op variabelen met "anders-categorie": hierin wordt bekeken of er bij de vragen met een antwoordcategorie "anders, namelijk..." bepaalde overeenkomstige antwoorden kunnen worden onderscheiden zodat vervolgens eventuele nieuwe antwoordcategorieën worden aangemaakt of dat de "anders-categorie" teruggebracht kan worden naar een al bestaande antwoordcategorie.

2. Doorvoeren van de verwijzingsstructuur: zijn er na een verwijzingsvraag minimaal 3 vervolgvragen ingevuld dan wordt het antwoord op de verwijzingsvraag zodanig aangepast dat de verwijzing niet opgevolgd wordt. Dit gebeurt alleen bij verwijzingsvragen met 2 antwoordmogelijkheden, zodat altijd duidelijk is welk antwoord de verwijzing negeert. Zijn er minder dan 3 vervolgvragen dan geldt dat alle vervolgvragen een geldig antwoord moeten hebben. Zodoende garandeert de verwijzingsvraag altijd een juist aantal cases op de vervolgvragen. Verder worden er verschillende codes toegepast op vragen die wel beantwoord hadden moeten worden, maar wat niet is gebeurd (onbekend) en op vragen die door een verwijzingsvraag niet beantwoord moeten worden (system missing).

3. Afronding cleaning: tot slot van de cleaning worden de cases die niet bruikbaar zijn uit het bestand verwijderd. Dit zijn onder andere de cases waarvan de afstudeerperiode niet correct is of cases waarvan meerdere cruciale basisvariabelen ontbreken.

3. Daarbij is een rechtstreekse koppeling mogelijk met de Standaard Onderwijs Indeling (SOI) van het CBS. 
$\mathrm{Na}$ de cleaning wordt het onderzoeksbestand uitgebreid met een aantal nieuwe samengestelde variabelen. Dit zijn variabelen die specifiek zijn gedefinieerd en/of op meerdere variabelen gebaseerd zijn (bijvoorbeeld de variabele 'beroepsbevolking').

\section{Weging}

De deelname van de scholen aan de schoolverlatersonderzoeken geschiedt zoals gezegd op vrijwillige basis. Hierdoor ontstaat er in de regel een ongelijke spreiding naar opleiding en regio. Ook naar andere kenmerken van de populatie kan er een niet-representatieve verdeling ontstaan. Zo is de respons bij vrouwen in het algemeen hoger dan bij mannen, waardoor vrouwen oververtegenwoordigd zijn in het onderzoeksbestand. Dergelijke omstandigheden leiden ertoe dat het onderzoeksbestand geen landelijke weergave is van de doelgroep. Om toch betrouwbare landelijke gegevens te kunnen presenteren, wordt een weging uitgevoerd op het bestand zoals dat na de dataverwerking is verkregen. Daarbij wordt een zodanige weging uitgevoerd dat de aantallen uiteindelijk corresponderen met de aantallen in de populatie.

Voor de weging wordt gebruik gemaakt van populatiegegevens die beschikbaar zijn op basis van de Integrale Leerlingtelling (ILT) (voor wat betreft het AVO, (I)VBO, BOL en BBL) en het Centraal Register Instellingen Hoger Onderwijs (CRIHO) (betreffende het HBO). Beide databestanden worden beheerd door het Ministerie van Onderwijs, Cultuur en Wetenschappen. De populatiegegevens van HBO Kunst en Cultuur zijn echter niet gebaseerd op de CRIHO-data. Deze bleek niet volledig betrouwbaar voor deze sector. Als populatie is daarom het totale aantal uitgezette vragenlijsten per kunstopleiding gebruikt. Dit is mogelijk omdat van de opleidingen die in de steekproef zitten iedereen benaderd wordt. Ten aanzien van de schoolverlaters van de landbouwopleidingen wordt gebruik gemaakt van overeenkomstige gegevens beschikbaar gesteld door het Ministerie van Landbouw, Natuurbeheer en Visserij. Voor wat betreft de WOopleidingen ten slotte, wordt geen weging, maar alleen een ophoging toegepast. De reden hiervoor is dat iedere afgestudeerde van het WO wordt benaderd en er dus geen sprake is van een steekproef.

De ILT 1997/1998 heeft per instelling en per opleiding gegevens beschikbaar over het aantal leerlingen per leerjaar en geslacht ${ }^{4}$. Het CRIHO bevat per instelling en opleiding gegevens over het aantal diploma's, waarbij eveneens een onderverdeling naar geslacht is gemaakt. Er wordt op het niveau van opleiding $x$ regio $x$ geslacht een weegfactor bepaald die de verhouding aangeeft tussen het populatie-aantal en het aantal respondenten in het onderzoeksbestand. Bij de weging van HBO-opleidingen wordt bovendien een onderscheid gemaakt tussen voltijd- en deeltijdopleidingen. Voor een aantal opleidingen heeft voorafgaand aan de weging een clustering van opleidingen plaatsgevonden. Op dit hogere clusterniveau wordt vervolgens de weging uitgevoerd. Gewogen wordt op het niveau van opleiding $x$ voltijd/deeltijd (alleen $\mathrm{HBO}$ ) $\mathrm{x}$ regio $x$ geslacht. Indien de resulterende weegfactor groter is dan 3 maal de gemiddelde weegfactor en als bovendien de steekproef kleiner is dan 50 , dan wordt het kenmerk geslacht en indien noodzakelijk ook het kenmerk regio buiten beschouwing gelaten. In dat geval wordt

4. Helaas zijn gegevens over het aantal gediplomeerden vanwege privacy-redenen tegenwoordig niet meer beschikbaar. Om toch rekening te houden met het rendement van het laatste leerjaar is gebruikt gemaakt van ILT-gegevens van het jaar daarvoor. 
gewogen op het niveau van opleiding $x$ voltijd/deeltijd (alleen HBO) $x$ regio, respectievelijk opleiding $x$ voltijd/deeltijd (alleen HBO). Tabel 3.1 geeft een overzicht van de aantallen schoolverlaters per opleidingssector vóór en ná de weging. Bij het HBO is daarbij een onderscheid gemaakt naar voltijd en deeltijd.

Tabel 3.1

Aantallen schoolverlaters per opleidingssector zowel voor weging als na weging

\begin{tabular}{|c|c|c|}
\hline Opleidingssector & $\begin{array}{l}\text { Ongewogen } \\
\text { aantal }\end{array}$ & $\begin{array}{l}\text { Gewogen } \\
\text { aantal }\end{array}$ \\
\hline $\begin{array}{l}\text { AVO } \\
\text { MAVO } \\
\text { HAVO } \\
\text { VWO }\end{array}$ & $\begin{array}{l}3.571 \\
1.061 \\
1.445 \\
1.065\end{array}$ & $\begin{array}{l}97.500 \\
41.400 \\
31.600 \\
24.500\end{array}$ \\
\hline $\begin{array}{l}\text { VBO } \\
\text { IVBO } \\
\text { landbouw } \\
\text { techniek } \\
\text { economie } \\
\text { gezondheidszorg }\end{array}$ & $\begin{array}{r}1.376 \\
207 \\
422 \\
295 \\
189 \\
263\end{array}$ & $\begin{array}{r}41.200 \\
4.700 \\
3.300 \\
15.800 \\
7.600 \\
9.800\end{array}$ \\
\hline $\begin{array}{l}\text { BOL niveau } 1 / 2 \\
\text { landbouw } \\
\text { techniek } \\
\text { economie } \\
\text { gezondheidszorg }\end{array}$ & $\begin{array}{r}680 \\
75 \\
139 \\
333 \\
133\end{array}$ & $\begin{array}{r}11.300 \\
300 \\
2.000 \\
7.100 \\
1.900\end{array}$ \\
\hline $\begin{array}{l}\text { BOL niveau } 3 / 4 \\
\text { landbouw } \\
\text { techniek } \\
\text { economie } \\
\text { gezondheidszorg } \\
\text { gedrag en maatschappij }\end{array}$ & $\begin{array}{r}6.056 \\
800 \\
1.304 \\
1.459 \\
1.220 \\
1.273\end{array}$ & $\begin{array}{r}40.200 \\
3.300 \\
10.000 \\
13.100 \\
6.200 \\
7.600\end{array}$ \\
\hline $\begin{array}{l}\text { BBL niveau } 1 / 2 \\
\text { techniek } \\
\text { economie } \\
\text { gezondheidszorg }\end{array}$ & $\begin{array}{l}572 \\
355 \\
102 \\
115\end{array}$ & $\begin{array}{r}12.300 \\
7.500 \\
3.700 \\
1.100\end{array}$ \\
\hline $\begin{array}{l}\text { BBL niveau } 3 / 4 \\
\text { techniek } \\
\text { economie } \\
\text { gezondheidszorg } \\
\text { gedrag en maatschappij }\end{array}$ & $\begin{array}{r}581 \\
272 \\
137 \\
105 \\
67\end{array}$ & $\begin{array}{r}14.000 \\
4.700 \\
2.600 \\
5.600 \\
1.100\end{array}$ \\
\hline $\begin{array}{l}\text { HBO voltijd } \\
\text { landbouw } \\
\text { onderwijs } \\
\text { techniek } \\
\text { economie } \\
\text { gezondheidszorg } \\
\text { gedrag en maatschappij } \\
\text { kunst en cultuur }\end{array}$ & $\begin{array}{r}13.572 \\
746 \\
1.595 \\
2.468 \\
3.961 \\
1.628 \\
2.089 \\
1.085\end{array}$ & $\begin{array}{r}42.300 \\
1.700 \\
6.800 \\
9.200 \\
12.600 \\
4.000 \\
5.600 \\
2.400\end{array}$ \\
\hline
\end{tabular}


Tabel 3.1 (vervolg)

Aantallen schoolverlaters per opleidingssector zowel voor weging als na weging

\begin{tabular}{lrr}
\hline Opleidingssector & $\begin{array}{c}\text { Ongewogen } \\
\text { aantal }\end{array}$ & $\begin{array}{c}\text { Gewogen } \\
\text { aantal }\end{array}$ \\
\hline HBO deeltijd & 2.042 & 9.200 \\
landbouw & 17 & 100 \\
onderwijs & 443 & 3.400 \\
techniek & 127 & 400 \\
economie & 384 & 1.800 \\
gezondheidszorg & 418 & 1.300 \\
gedrag en maatschappij & 528 & 2.000 \\
kunst en cultuur & 125 & 200 \\
WO & & \\
landbouw & 8.152 & 18.400 \\
techniek & 276 & 600 \\
economie & 1.295 & 2.900 \\
gezondheidszorg & 1.255 & 2.800 \\
gedrag en maatschappij & 1.009 & 2.300 \\
taal en cultuur & 1.609 & 3.600 \\
recht en openbare orde & 1.043 & 2.400 \\
natuurwetenschappen & 1.014 & 2.300 \\
& 651 & 1.500 \\
\hline
\end{tabular}

\section{Dekkingsgraad en respons}

De schoolverlaters die uiteindelijk in het onderzoeksbestand zijn opgenomen, vormen slechts een gedeelte van de gehele onderzoekspopulatie. Enerzijds worden niet álle personen uit de doelgroep benaderd en anderzijds reageert niet iedereen die wél is benaderd. De dekkingsgraad geeft een beeld van de omvang van het gedeelte van de populatie dat benaderd is. Het responspercentage geeft vervolgens aan welk deel van degenen die benaderd zijn daadwerkelijk heeft gereageerd.

\section{Dekkingsgraad}

Tabel 4.1 laat voor 2000 zien hoe groot de dekkingsgraad per onderwijssoort is. Uit de tabel blijkt dat ertussen de onderwijssoorten een groot verschil in dekkingsgraad bestaat. De dekkingsgraad bij zowel het AVO als het (I)VBO is laag (respectievelijk $8 \%$ en $9 \%$ ) en gedaald vergeleken met 1999. Ook BOL niveau $1 / 2$ en BBL niveau $3 / 4$ laten een daling van de dekkingsgraad zien ten opzichte van vorig jaar. Bij het $\mathrm{HBO}$ is er wederom sprake van een hoge deelname. Hier wordt een dekkingsgraad van $76 \%$ bereikt. De dekkingsgraad van HBO Kunst en Cultuur kan niet worden weergegeven, omdat de populatiegegevens gelijk zijn aan het aantal uitgezette vragenlijsten (zie paragraaf 3 ). Bij het WO zijn de cijfers over de dekkingsgraad niet weergegeven, omdat er sprake is van een integrale meting.

5. De aantallen van het WO hebben betrekking op 12 van de 13 universiteiten. 
Tabel 4.1

Dekkingsgraad per onderwijssoort

$\begin{array}{cc}\text { Benaderd } & \text { Dekking } \\ \text { aantal } & \%\end{array}$

AVO
MAVO
HAVO
VWO
VBO
IVBO
landbouw
techniek
economie
gezondheidszorg

$\begin{array}{ll}8.247 & 8\end{array}$

$\begin{array}{ll}8.773 & 7\end{array}$

$3.388 \quad 11$

$2.086 \quad 9$

$3.908+9$

639

$905-27$

$\begin{array}{ll}1.039 & 7\end{array}$

$687 \quad 9$

$\begin{array}{ll}638 & 7\end{array}$

BOL niveau $1 / 2$

2.645

landbouw $\quad 167 \quad 54$

techniek $\quad 663 \quad 33$

economie $\quad 1.353 \quad 19$

$\begin{array}{lll}\text { gezondheidszorg } & 462 & 25\end{array}$

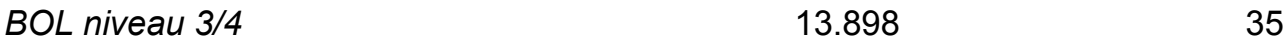

$\begin{array}{lll}\text { landbouw } & 1.589 & 47\end{array}$

techniek 3.314

economie $\quad 3.723 \quad 28$

gezondheidszorg $\quad 2.482 \quad 40$

$\begin{array}{lll}\text { gedrag en maatschappij } & 3.790 & 37\end{array}$

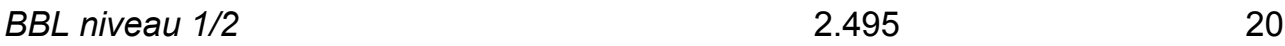

techniek $\quad 1.547 \quad 21$

economie $\quad 546 \quad 15$

$\begin{array}{lll}\text { gezondheidszorg } & 402 & 37\end{array}$

$\begin{array}{lll}B B L & \text { niveau 3/4 } & 2.191\end{array}$

techniek $\quad 1.057 \quad 22$

economie $\quad 578 \quad 22$

gezondheidszorg 354

$\begin{array}{lll}\text { gedrag en maatschappij } & 202 & 18\end{array}$

$\begin{array}{lll}\mathrm{HBO}^{6} & 36.524 & 76\end{array}$

$\begin{array}{lll}\text { landbouw } & 1.833 & 100\end{array}$

$\begin{array}{lll}\text { onderwijs } & 4.746 & 47\end{array}$

$\begin{array}{lrr}\text { techniek } & 7.510 & 78\end{array}$

$\begin{array}{lcc}\text { economie } & 11.674 & 81\end{array}$

$\begin{array}{lll}\text { gezondheidszorg } & 4.541 & 87\end{array}$

$\begin{array}{lll}\text { gedrag en maatschappij } & 6.320 & 83\end{array}$

6. Exclusief HBO Kunst en Cultuur.

8 


\section{Respons}

Zoals uit tabel 4.2 blijkt is de respons ${ }^{7}$ het hoogst bij de schoolverlaters van het AVO $(47 \%)$. $\mathrm{BOL}$ niveau $3 / 4$ en WO volgen met $46 \%$. De respons van BBL niveau $1 / 2$ is het laagst, namelijk $28 \%$. In 1999 was er al een daling van de respons ten opzichte van 1998, deze daling heeft zich in 2000 doorgezet. Wat verder opvalt is dat er binnen iedere onderwijssoort sprake is van een vrij grote spreiding in de responspercentages. Met name bij VBO en BOL niveau 1/2 zijn de verschillen tussen opleidingssectoren groot.

Tabel 4.2

Responspercentage per opleidingssector

$\begin{array}{ll}\text { Opleidingssector } & \%\end{array}$

$\begin{array}{lr}\text { AVO } & 47 \\ \text { MAVO } & 42 \\ \text { HAVO } & 46 \\ \text { VWO } & 54 \\ \text { VBO } & 40 \\ \text { IVBO } & 38 \\ \text { landbouw } & 52 \\ \text { techniek } & 32 \\ \text { economie } & 32 \\ \text { gezondheidszorg } & 47 \\ \text { BOL niveau 1/2 } & \\ \text { landbouw } & 30 \\ \text { techniek } & 50 \\ \text { economie } & 25 \\ \text { gezondheidszorg } & 28 \\ \text { BOL niveau 3/4 } & 34 \\ \text { landbouw } & \\ \text { techniek } & 46 \\ \text { economie } & 53 \\ \text { gezondheidszorg } & 41 \\ \text { gedrag en maatschappij } & 42 \\ \text { BBL niveau 1/2 } & 51 \\ \text { techniek } & 47 \\ \text { economie } & \\ \text { gezondheidszorg } & 28 \\ \text { BBL niveau 3/4 } & 28 \\ \text { techniek } & 25 \\ \text { economie } & 32 \\ \text { gezondheidszorg en maatschappij } & \\ & 31 \\ & 31 \\ & 28 \\ & 35 \\ & 36\end{array}$

7. Voor de berekeningswijze van de respons zie Willems en Van der Linden (1998). 
Tabel 4.2 (vervolg)

Responspercentage per opleidingssector

Opleidingssector

$\%$

$\begin{array}{lr}H B O & 40 \\ \text { landbouw } & 44 \\ \text { onderwijs } & 37 \\ \text { techniek } & 36 \\ \text { economie } & 39 \\ \text { gezondheidszorg } & 47 \\ \text { gedrag en maatschappij } & 43 \\ \text { kunst en cultuur } & 33 \\ \text { wO }^{8} & \\ \text { landbouw } & 46 \\ \text { techniek } & 52 \\ \text { economie } & 49 \\ \text { gezondheidszorg } & 40 \\ \text { gedrag en maatschappij } & 49 \\ \text { taal en cultuur } & 52 \\ \text { recht en openbare orde } & 46 \\ \text { natuurwetenschappen } & 39 \\ & 51\end{array}$

Door middel van een responsanalyse is geprobeerd een beter inzicht te krijgen in de factoren die van invloed zijn op de respons. Aangezien er (per definitie) vrij weinig gegevens bekend zijn over de schoolverlaters die niet gerespondeerd hebben, is de responsanalyse noodzakelijkerwijs beperkt. Er is informatie aanwezig over drie factoren die mogelijk invloed hebben op de respons. Ten eerste is informatie over de gevolgde opleiding van de aangeschreven schoolverlaters aanwezig. Ten tweede is de wijze van verzending van de vragenlijsten bekend. De vragenlijsten kunnen enerzijds centraal door DESAN aan de afgestudeerden worden toegestuurd; anderzijds kunnen de onderwijsinstellingen de vragenlijsten zelf verzenden. Dit laatste noemen we decentrale verzending. Ten derde is de regioverdeling in de steekproef bekend.

Wellicht geldt dat het responspercentage in de ene regio hoger ligt dan in de andere. Wanneer een bepaalde regio in de loop der jaren een steeds belangrijkere rol is gaan vervullen in de steekproef en als de respons tussen regio's inderdaad verschilt, dan kan dit een verklaring zijn voor veranderingen in de totale respons. Een soortgelijke situatie kan natuurlijk ook gelden voor het opleidingsniveau dat schoolverlaters hebben voltooid. Met behulp van logistische regressieanalyse is nagegaan wat de invloed is van deze drie factoren op de respons. De resultaten van deze analyse staan weergegeven in tabel 4.3.

De analyse toont dat, gecorrigeerd voor regio en wijze van verzending, schoolverlaters van het AVO en het WO het vaakst responderen. De respons onder de schoolverlaters van BBL niveau $1 / 2$ is relatief gezien het laagst. Beide bevindingen bevestigen het beeld dat al in tabel 4.2 is aangetroffen. Verder blijkt dat de respons geografisch ongelijkmatig verdeeld is. Met name in

8. De gepresenteerde responspercentages hebben betrekking op 12 van de 13 universiteiten. 
het westen en het noorden is de respons laag. Daarnaast blijkt dat decentraal verzenden een significant hogere respons oplevert ten opzichte van centrale verzending van vragenlijsten.

Tabel 4.3

De invloed van onderwijssoort, regio en wijze van verzending op respons: logit effecten

Onafhankelijke variabelen

Parameter

Standaardfout

constante

$-0,12^{* *} \quad 0,02$

onderwijssoort:

AVO

VBO

BOL $1 / 2$

$0,00 \quad 0,03$

BOL $3 / 4$

$-0,24^{* *}$

0,04

BBL $1 / 2$

$-0,71^{* *}$

0,05

$\mathrm{BBL} 3 / 4$

$-0,03$

0,02

HBO

$-0,79^{* *}$

0,05

WO

$-0,29^{* *}$

0,05

0,02

regio:

noord
$-0,11^{* *}$
0,02
0,06
0,02
$-0,13^{* *}$
0,02
referentiecategorie

oost

west

zuid

decentrale verzending

$0,27^{* *}$

0,02

$N=90.679$

** significant op 1\%-niveau

Tabel 4.4 geeft tot slot een overzicht van de aantallen in 2000 uitgezette en teruggestuurde vragenlijsten. Dit overzicht geeft bovendien enkele redenen weer waarom sommige teruggestuurde vragenlijsten niet geschikt zijn voor verwerking. De belangrijkste reden hiervoor is het ontbreken van een juist adres (4\%). Onder overige redenen vallen met name afgestudeerden die onbereikbaar waren vanwege bijvoorbeeld een verblijf in het buitenland of ziekte. 


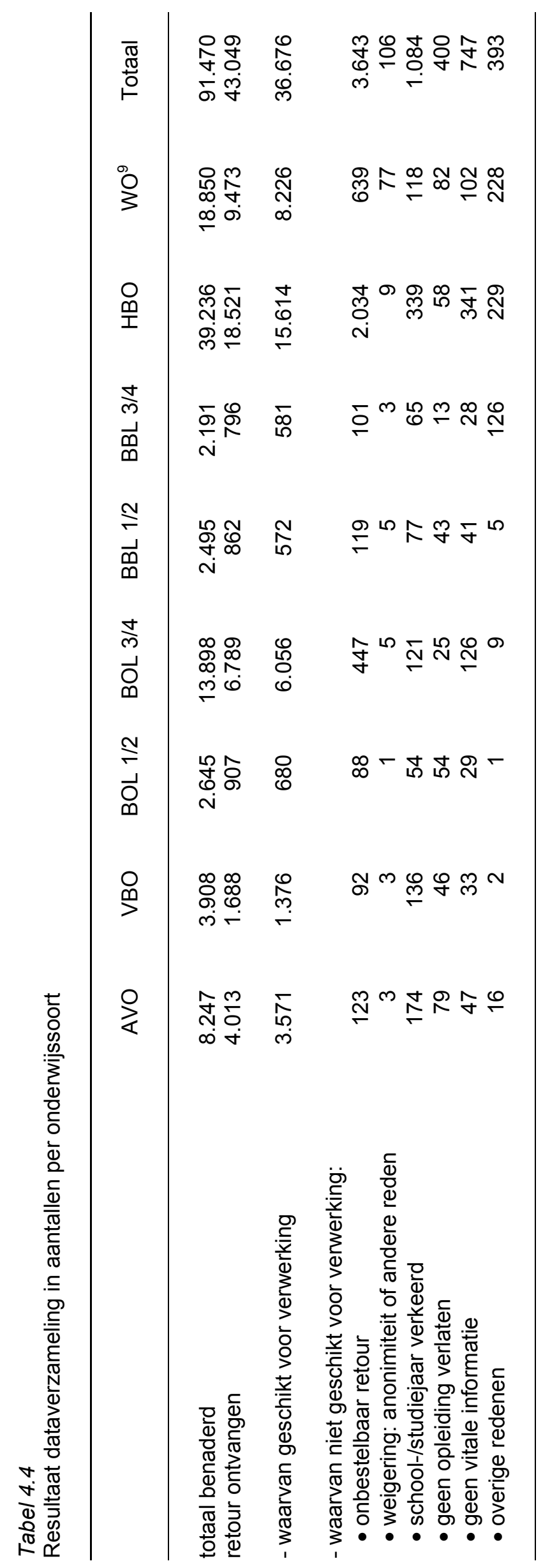

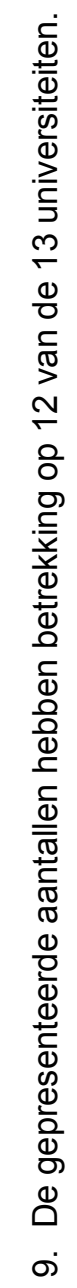




\section{Non-respons}

Zoals in de vorige paragraaf reeds is vermeld varieert het responspercentage tussen de $28 \%$ (BBL niveau 1/2) en 47\% (AVO). De resultaten zoals die beschreven staan in de landelijke rapporten en instellingsrapportages hebben betrekking op deze responsgroep. Om te achterhalen of de onderzoeksresultaten die gebaseerd zijn op de gegevens van deze responsgroep geen vertekening van de werkelijkheid vormen, is het van belang na te gaan of er sprake is van een selectieve (non-)respons. Het mag niet zo zijn dat de groep respondenten en de groep nonrespondenten op kenmerken van elkaar verschillen. Als bijvoorbeeld de schoolverlaters die werkloos zijn grotendeels weigeren aan de enquête deel te nemen ontstaat er wat betreft het kenmerk werkloosheid een verschil tussen de non-responsgroep en de responsgroep. Dit zal vervolgens leiden tot een onderschatting van het werkelijke werkloosheidspercentage, indien dit wordt berekend op basis van de gegevens van de responsgroep.

Eventuele selectiviteit van de (non-)respons kan worden nagegaan door op enkele belangrijke kenmerken de responsgroep met de non-responsgroep te vergelijken. Dit is op twee manieren mogelijk:

1. door kenmerken van de responsgroep te vergelijken met kenmerken van de doelgroeppopulatie die reeds op basis van andere bronnen bekend zijn, of;

2. door een aanvullend onderzoek te houden onder de non-responsgroep, waarbij over enkele kernvariabelen informatie wordt ingewonnen.

Ten behoeve van het schoolverlatersonderzoek is vooraf nauwelijks enige informatie over de populatie bekend behalve over de gevolgde opleiding, het geslacht van de schoolverlaters en de regio van de opleiding. Deze populatiegegevens worden reeds gebruikt om het onderzoeksbestand te wegen waardoor op deze punten een landelijk representatief beeld ontstaat zodat voor het nagaan van de mate van selectiviteit van de (non-)respons derhalve een nonresponsonderzoek noodzakelijk is.

De vraag is vervolgens over welke kenmerken van de non-responsgroep informatie verzameld dient te worden. Het antwoord wordt bepaald door het belang dat binnen het schoolverlatersonderzoek aan verschillende kenmerken wordt gehecht en de mate waarin verwacht mag worden dat de respons op deze punten selectief is. De bestemming oftewel de maatschappelijke positie van schoolverlaters na het verlaten van de opleiding kan beschouwd worden als één van de belangrijkste kernpunten in de schoolverlatersenquêtes. Bovendien zou juist op dit punt selectiviteit in de (non-)respons kunnen ontstaan. Evenals in voorgaande jaren is het nonresponsonderzoek voor het uitvoeringsjaar 2000 daarom vooral toegespitst op de bestemming van schoolverlaters.

Een ander belangrijk aspect binnen het schoolverlatersonderzoek omvat het onderzoek onder degenen die betaald werk verrichten. Daarom wordt in het non-responsonderzoek ook getoetst op eventuele selectiviteit in het antwoord op de vraag 'Heb je op dit moment (ook) betaald werk? (inclusief een betaalde bijbaan en/of een leer-arbeidsplaats)'. 
Het non-responsonderzoek voor 2000 heeft plaatsgevonden aan de hand van een korte telefonische enquête onder afgestudeerden van het $\mathrm{HBO}$ en het WO die in eerste instantie niet hebben gereageerd ${ }^{10}$. Naar onderwijssoort wordt een gestratificeerde steekproef getrokken, dat wil zeggen een aselecte steekproef over de verschillende opleidingssectoren. Dit heeft geleid tot 490 respondenten in het non-responsonderzoek. De opleidingssectoren HBO kunst en cultuur en HBO pedagogisch onderwijs vormen een uitzondering op deze steekproeftrekking: hier zijn de non-respondenten, zoals eerder is aangegeven, al telefonisch benaderd.

Voor het uitvoeren van het telefonisch onderzoek onder de non-respondenten is dit jaar gebruik gemaakt van één vragenlijst voor zowel non-respondenten van het $\mathrm{HBO}$ als van het WO. Aan de hand van die lijst is informatie verzameld over de gevolgde opleiding van de non-respondent, over de belangrijkste bezigheid op het moment van enquêteren en (indien van toepassing) over de huidige baan. Aan alle non-respondenten is tevens gevraagd naar de reden waarom men in eerste instantie niet heeft deelgenomen aan het onderzoek.

Tabel 5.1 laat per onderwijssoort zien wat de redenen van weigering door de non-respondenten zijn geweest. Hierbij gaat het dus om de non-respondenten die in eerste instantie niet hebben deelgenomen aan het onderzoek, maar wel aan de telefonische enquête. De belangrijkste reden waarom schoolverlaters de vragenlijst niet hebben ingevuld en teruggestuurd is dat het invullen ervan teveel tijd of moeite kost.

Tabel 5.1

Redenen van schoolverlaters om de schriftelijke vragenlijst niet in te vullen en terug te sturen in percentages per onderwijssoort

\begin{tabular}{lccc}
\hline Reden & HBO & WO & Totaal \\
& $\%$ & $\%$ & $\%$ \\
& & & \\
\hline & 11 & 16 & 14 \\
geen echte reden & 12 & 17 & 15 \\
vragenlijst nooit ontvangen & 6 & 3 & 4 \\
vragenlijst kwijtgeraakt & 10 & 11 & 10 \\
geen interesse & 8 & 13 & 11 \\
invullen kost teveel tijd en/of moeite & 41 & 29 & 34 \\
bedenkingen bij anonimiteit en/of privacy & 2 & 0 & 1 \\
vragenlijst was niet op mij van toepassing & 3 & 2 & 2 \\
andere redenen & 9 & 10 & 10 \\
\end{tabular}

10. Om financiële redenen heeft er in 2000 geen non-response onderzoek plaatsgevonden in de RUBSenquête. 
Vervolgens kan worden nagegaan of de responsgroep en de groep die aanvankelijk niet op de schriftelijke enquête heeft gereageerd van elkaar verschillen voor wat betreft de kernvariabelen 'bestemming' en 'betaald werk'. De significantie van dit verschil wordt bepaald aan de hand van de toets van Fisher (zie bijvoorbeeld Van der Genugten, 1986: pp. 298-304). Voordat deze Fisher-toets kan worden toegepast, is het echter noodzakelijk om enkele aanpassingen in de databestanden van zowel de non-responsgroep als de responsgroep door te voeren. Allereerst zijn de afgestudeerden van het kunstonderwijs en het hoger pedagogisch onderwijs die telefonisch gereageerd hebben, overgeheveld van de responsgroep naar de non-responsgroep. Voor onderzoeksdoeleinden behoren ze weliswaar tot de normale respons, maar gezien het feit dat ze de schriftelijke vragenlijst niet hebben geretourneerd, worden ze in het non-respons onderzoek beschouwd als non-respons.

Verder is de verdeling naar opleidingssector verschillend tussen het responsbestand en het non-responsbestand. Om hiervoor te corrigeren - en dus beide bestanden op dit punt vergelijkbaar te maken - is het responsbestand zodanig (opnieuw) gewogen dat de verdeling over de opleidingssectoren overeenkomt met die van het non-responsbestand ${ }^{11}$. Tabel 5.2 laat per onderwijssoort voor elke bestemmingscategorie het resultaat van de toets van Fisher zien. Voor de volledigheid is aangegeven hoe de bestemming van de non-responsgroep en de responsgroep er in aantallen en percentages uit ziet. De aantallen voor de responsgroep zijn daarbij, zoals gezegd, zodanig aangepast dat de verdeling van de schoolverlaters over de opleidingssectoren binnen de desbetreffende onderwijssoort gelijk is aan de verdeling binnen deze onderwijssoort in het non-responsbestand ${ }^{12}$.

De aantallen in de twee kolommen vormen de basis voor het berekenen van de z-score. Wat opvalt in tabel 5.2 is dat met name op HBO-niveau veel significante verschillen zijn tussen de non-respons en de responsgroep. Dit valt echter gedeeltelijk te verklaren door de grote aantallen respondenten die zijn ondervraagd.

Eventuele selectiviteit tussen de respons en de non-responsgroep in het antwoord op de vraag 'Heb je op dit moment (ook) betaald werk? (inclusief een betaalde bijbaan en/of een leerarbeidsplaats)' staat weergegeven in tabel 5.3. De term betaald werk in tabel 5.2 is overigens niet dezelfde als het aandeel betaald werkenden waarnaar in tabel 5.3 wordt gekeken. Tabel 5.2 heeft betrekking op de activiteit die respondenten als hun belangrijkste bezigheid ervaren, terwijl er in tabel 5.3 wordt gekeken of iemand betaald werk heeft of niet, ongeacht of men dit de belangrijkste bezigheid vindt. Uit tabel 5.3 blijkt dat er geen verschil is tussen de non-respondenten en de respondenten van het HBO met betrekking tot betaald werk. De non-responsgroep bij het WO beschikt daarentegen over een significant geringer aandeel respondenten met betaald werk.

11. In principe zou het ook mogelijk zijn geweest om het non-responsbestand te herwegen naar het (al dan niet gewogen) responsbestand. Aangezien het non-responsbestand sterk scheef verdeeld is over de opleidingssectoren, zou dit leiden tot zeer hoge en dus onbetrouwbare weegfactoren.

12. Uiteraard zou men de verdelingen nog meer op elkaar kunnen afstemmen door bijvoorbeeld ook rekening te houden met het kenmerk geslacht. Dit is echter niet gedaan, omdat de aantallen in het non-responsbestand daarvoor te klein zijn. 
Tabel 5.2

Toets van Fisher op selectiviteit naar bestemming tussen respondenten en non-respondenten per onderwijssoort

\begin{tabular}{|c|c|c|c|c|c|}
\hline \multirow[t]{2}{*}{ Bestemming } & \multicolumn{2}{|c|}{ Non-respons ${ }^{a}$} & \multicolumn{2}{|c|}{ Respons $^{\mathrm{b}, \mathrm{c}}$} & \multirow[t]{2}{*}{ Z-score } \\
\hline & aantal & $\%$ & aantal & $\%$ & \\
\hline \multicolumn{6}{|l|}{$H B O$} \\
\hline betaald werk & 968 & 87 & 15.721 & 84 & $2,20^{*}$ \\
\hline studie & 89 & 8 & 2.264 & 12 & $-4,17^{* *}$ \\
\hline werkloos & 26 & 2 & 343 & 2 & 1,18 \\
\hline anders & 35 & 3 & 361 & 2 & $2,78^{*}$ \\
\hline \multicolumn{6}{|l|}{$W O^{13}$} \\
\hline betaald werk & 261 & 92 & 3.799 & 92 & 0,67 \\
\hline studie & 6 & 2 & 164 & 4 & $-1,95$ \\
\hline werkloos & 11 & 4 & 87 & 2 & $4,56^{* *}$ \\
\hline anders & 5 & 2 & 101 & 2 & $-1,64$ \\
\hline
\end{tabular}

a. Inclusief telefonische respons (kunst- en pedagogisch onderwijs)

b. Exclusief telefonische respons (kunst- en pedagogisch onderwijs)

c. Gewogen naar de verdeling over de opleidingssectoren in het non-responsbestand. De hier gepresenteerde aantallen wijken derhalve af van de in de (landelijke) rapportages genoemde aantallen

* Significant op 5\%-niveau

** Significant op $1 \%$-niveau

Tabel 5.3

Toets van Fisher op selectiviteit in het aandeel betaald werkende respondenten en het aandeel betaald werkende non-respondenten per onderwijssoort

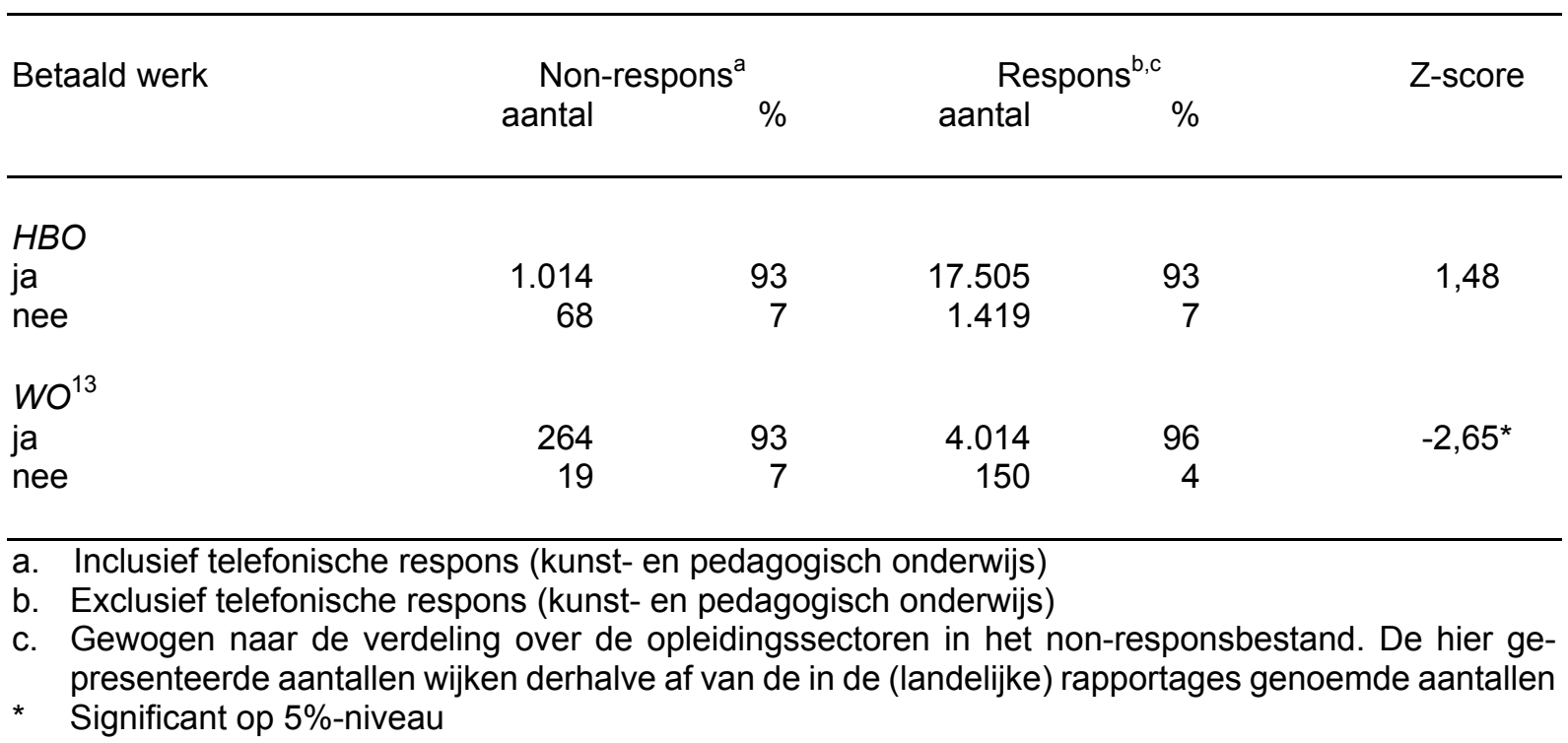

13. De resultaten hebben betrekking op 12 van de 13 universiteiten. 


\section{Invullen vragenlijst via internet of schriftelijk}

In het schoolverlatersonderzoek van 2000 werd de mogelijkheid geïntroduceerd de vragenlijst via internet in te vullen. Schoolverlaters hadden de keuze de vragenlijst schriftelijk of via internet te beantwoorden. In de praktijk heeft echter niet iedereen die keuze gehad. De schoolverlaters van

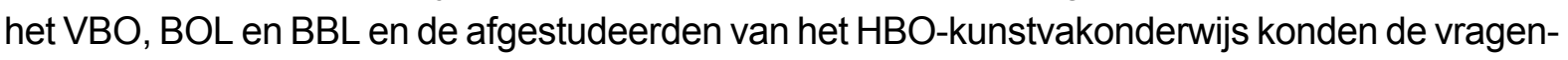
lijst alleen schriftelijk invullen. Hetzelfde gold ook voor afgestudeerden van scholen die de vragenlijst zelf verzonden en afgestudeerden van scholen/opleidingsrichtingen met een apart inlegvel.

Uit tabel 6.1 blijkt dat van de schoolverlaters van het AVO en van de afgestudeerden van het HBO en WO die de vragenlijst hebben ingevuld, 44\% de mogelijkheid heeft gehad deze vragenlijst via internet in te vullen. Daarvan heeft $27 \%$ ook daadwerkelijk via internet gereageerd. De respons via internet is het hoogst bij de afgestudeerden van het WO (30\%). Bij het $\mathrm{HBO}$ en het AVO is de respons via internet gelijk (25\%). Binnen het WO wordt bij de sector natuurwetenschappen het meest gebruik gemaakt van de internetmogelijkheid (41\%), bij het $\mathrm{HBO}$ is dit de sector techniek (34\%) en bij het AVO zijn dit de schoolverlaters van het VWO $(30 \%)$. Bij de sector HBO onderwijs vult slecht $19 \%$ de vragenlijst via internet in.

Tabel 6.1

Invullen vragenlijst via internet

Opleidingssector

Keuzemogelijkheid internet

Daadwerkelijk via internet gereageerd

$\%$ aantal $\%$

AVO 59

MAVO

VWO

HBO 58

landbouw

techniek

1.458

1.462

2.920

1.100

WO

techniek

economie

gezondheidszorg

gedrag en maatschappij

taal en cultuur

recht en openbare orde

natuurwetenschappen

totaal

\section{2}

72

100

56

89

60

68

75

81

44
4.700

948

553

779

749

546

625

425

15.922 
De vraag is vervolgens of de mogelijkheid tot het invullen van de vragenlijst via internet ook gevolgen heeft voor de samenstelling van de respons(-groep). Om te kijken of de groep die de vragenlijst via internet invult verschilt van de groep die de vragenlijst schriftelijk invult, zijn van beide groepen achtergrondkenmerken en kenmerken van hun vervolgbestemming naast elkaar gezet.

\section{Achtergrondkenmerken}

Met behulp van logistische regressieanalyse is allereerst nagegaan wat de afzonderlijke invloed van de achtergrondkenmerken geslacht, leeftijd en etniciteit op de respons via internet is. De resultaten van deze analyse staan weergegeven in tabel 6.2.

Tabel 6.2

De invloed van opleidingssector, geslacht, leeftijd en etniciteit op respons via internet: logit effecten

\begin{tabular}{|c|c|c|}
\hline Onafhankelijke variabelen & Parameter & Standaardfout \\
\hline constante & $-0,84^{* *}$ & 0,15 \\
\hline \multicolumn{3}{|l|}{ onderwijssector: } \\
\hline MAVO & $-0,81^{\star *}$ & 0,15 \\
\hline HAVO & $-0,69^{* *}$ & 0,14 \\
\hline VWO & $-0,39^{* *}$ & 0,14 \\
\hline HBO landbouw & $-0,79^{* *}$ & 0,14 \\
\hline HBO onderwijs & $-0,66^{* *}$ & 0,13 \\
\hline HBO techniek & $-0,38^{* *}$ & 0,12 \\
\hline HBO economie & $-0,58^{* *}$ & 0,12 \\
\hline HBO gezondheidszorg & $-0,90^{* *}$ & 0,13 \\
\hline HBO gedrag en Maatschappij & $-0,93^{* *}$ & 0,13 \\
\hline WO techniek & $-0,58^{* *}$ & 0,13 \\
\hline WO economie & $-0,52^{* *}$ & 0,14 \\
\hline WO gezondheidszorg & $-0,59^{\star *}$ & 0,14 \\
\hline WO gedrag en maatschappij & $-0,44^{* *}$ & 0,14 \\
\hline WO taal en cultuur & $-0,26$ & 0,16 \\
\hline WO recht en openbare orde & $-0,95^{* *}$ & 0,16 \\
\hline WO natuurwetenschappen & \multicolumn{2}{|c|}{ referentiecategorie } \\
\hline man & $0,27^{* *}$ & 0,04 \\
\hline leeftijd & $0,01^{* *}$ & 0,00 \\
\hline allochtoon & $0,20^{* *}$ & 0,07 \\
\hline$N=14.633$ & & \\
\hline
\end{tabular}

** significant op $1 \%$-niveau

De analyse toont dat, gecorrigeerd voor geslacht, leeftijd en etniciteit, de afgestudeerden van WO natuurwetenschappen het vaakst via internet reageren. Dit bleek ook al uit tabel 6.1. 
Afgestudeerden van de sectoren HBO gedrag en maatschappij en WO recht en openbare orde reageren daarentegen het minst vaak via internet. Tabel 6.2 toont verder dat mannen en allochtonen significant vaker via internet reageren dan vrouwen en autochtonen. De invloed van leeftijd op de respons via internet is, ondanks dat het effect significant is, gering.

De vraag is vervolgens of de responsgroep binnen opleidingen nu verandert door de effecten van geslacht, leeftijd en etniciteit. Tabel 6.3 geeft een overzicht per opleidingssector naar deze achtergrondkenmerken voor twee groepen. De eerste groep heeft de vragenlijst via internet ingevuld en de tweede groep heeft de vragenlijst schriftelijk ingevuld.

Tabel 6.3

Opleidingssector naar geslacht, leeftijd en etniciteit

\begin{tabular}{|c|c|c|c|c|c|c|}
\hline \multirow[t]{2}{*}{ Opleidingssector } & \multicolumn{3}{|c|}{ Internet } & \multicolumn{3}{|c|}{ Schriftelijk } \\
\hline & $\begin{array}{r}\operatorname{man} \\
\%\end{array}$ & $\begin{array}{c}\text { leeftijd } \\
\text { gem. }\end{array}$ & $\begin{array}{r}\text { alloch- } \\
\text { toon } \\
\%\end{array}$ & $\begin{array}{r}\text { man } \\
\%\end{array}$ & $\begin{array}{l}\text { leeftijd } \\
\text { gem. }\end{array}$ & $\begin{array}{r}\text { alloch- } \\
\text { toon } \\
\%\end{array}$ \\
\hline AVO & 55 & 18 & 9 & 44 & 18 & 8 \\
\hline MAVO & 57 & 17 & 9 & 44 & 17 & 8 \\
\hline HAVO & 54 & 19 & 8 & 45 & 19 & 8 \\
\hline VWO & 53 & 19 & 9 & 43 & 19 & 6 \\
\hline $\mathrm{HBO}$ & 54 & 27 & 7 & 43 & 26 & 5 \\
\hline landbouw & 66 & 25 & 1 & 67 & 25 & 2 \\
\hline onderwijs & 26 & 30 & 5 & 19 & 29 & 5 \\
\hline techniek & 86 & 25 & 9 & 85 & 25 & 5 \\
\hline economie & 60 & 27 & 6 & 49 & 26 & 5 \\
\hline gezondheidszorg & 23 & 26 & 6 & 18 & 26 & 3 \\
\hline gedrag en maatschappij & 23 & 27 & 8 & 18 & 26 & 7 \\
\hline WO & 52 & 28 & 8 & 45 & 28 & 7 \\
\hline techniek & 80 & 27 & 8 & 76 & 27 & 8 \\
\hline economie & 77 & 27 & 8 & 63 & 26 & 10 \\
\hline gezondheidszorg & 38 & 28 & 9 & 32 & 29 & 10 \\
\hline gedrag en maatschappij & 28 & 29 & 7 & 25 & 29 & 4 \\
\hline taal en cultuur & 25 & 29 & 8 & 25 & 29 & 5 \\
\hline recht en openbare orde & 46 & 28 & 9 & 40 & 28 & 9 \\
\hline natuurwetenschappen & 56 & 25 & 9 & 51 & 26 & 4 \\
\hline totaal & 54 & 22 & 8 & 44 & 22 & 7 \\
\hline
\end{tabular}

Voor bijna alle opleidingen geldt dat mannen en allochtonen oververtegenwoordigd zijn in de internetgroep. Door de internetmogelijkheid zullen mannen en allochtonen waarschijnlijk meer gaan responderen. Dit is gunstig te noemen, want de respons op enquetes onder mannen en allochtonen is over het algemeen lager dan onder vrouwen en autochtonen (zie paragraaf 3). Met betrekking tot de gemiddelde leeftijd zijn er nauwelijks verschillen tussen beide groepen te vinden. 


\section{Bestemmingskenmerken}

Wederom is eerst met behulp van logistische regressieanalyse nagegaan wat de afzonderlijke invloed is van enkele bestemmingskenmerken op de respons via internet. De volgende kenmerken zijn onderzocht: "vervolgopleiding gevolgd", "aanbieden op de arbeidsmarkt", "werkloosheid", "vaste aanstelling" en "bruto uurloon". Allereerst is gekeken naar de invloed van deze kenmerken op de respons via internet zonder rekening te houden met achtergrondkenmerken. Daarna is gekeken naar de invloed van deze kenmerken indien er wel rekening wordt gehouden met de effecten van opleiding, geslacht, leeftijd en etniciteit. De resultaten staan weergegeven in tabel $6.4^{14}$.

Tabel 6.4

De invloed van bestemmingskenmerken op respons via internet: logit effecten

Onafhankelijke variabelen $\quad$ Parameter Standaardfout

$\begin{array}{lcc}\text { exclusief effecten van achtergrondvariabelen } & & \\ \text { vervolgopleiding gevolgd } & 0,28^{* *} & 0,05 \\ \text { aanbieden op de arbeidsmarkt } & -0,32^{\star *} & 0,07 \\ \text { werkloosheid } & 0,09 & 0,14 \\ \text { vaste aanstelling } & 0,05 & 0,07 \\ \text { bruto uurloon } & 0,00 & 0,00 \\ \text { inclusief effecten van achtergrondvariabelen } & & \\ \text { vervolgopleiding gevolgd } & 0,27^{* *} & 0,07 \\ \text { aanbieden op de arbeidsmarkt } & -0,35^{\star *} & 0,07 \\ \text { werkloosheid } & 0,11 & 0,14 \\ \text { vaste aanstelling } & -0,02 & 0,08 \\ \text { bruto uurloon } & 0,00 & 0,00\end{array}$

** significant op 1\%-niveau

Afgestudeerden van het $\mathrm{HBO}$ en het WO die een vervolgopleiding volgen hebben een significant hogere respons via internet. Daarentegen hebben afgestudeerden van HBO en WO die zich aanbieden op de arbeidsmarkt juist een significant lagere respons via internet. De bestemmingskenmerken "werkloosheid", "vaste aanstelling" en "bruto uurloon" hebben geen invloed op de respons via internet. Wanneer er rekening wordt gehouden met de achtergrondvariabelen verandert de invloed van de bestemmingskenmerken op de respons via internet nauwelijks.

Wat betekenen deze bevindingen nu voor de samenstelling van de responsgroep? Tabel 6.5 geeft een overzicht van afgestudeerden van het HBO en WO met betrekking tot de bestemmingkenmerken.

14. Schoolverlaters van het AVO is in deze paragraaf buiten beschouwing gelaten omdat er geen informatie over hun arbeidsmarktpositie in de meting van 2000 is gevraagd. 


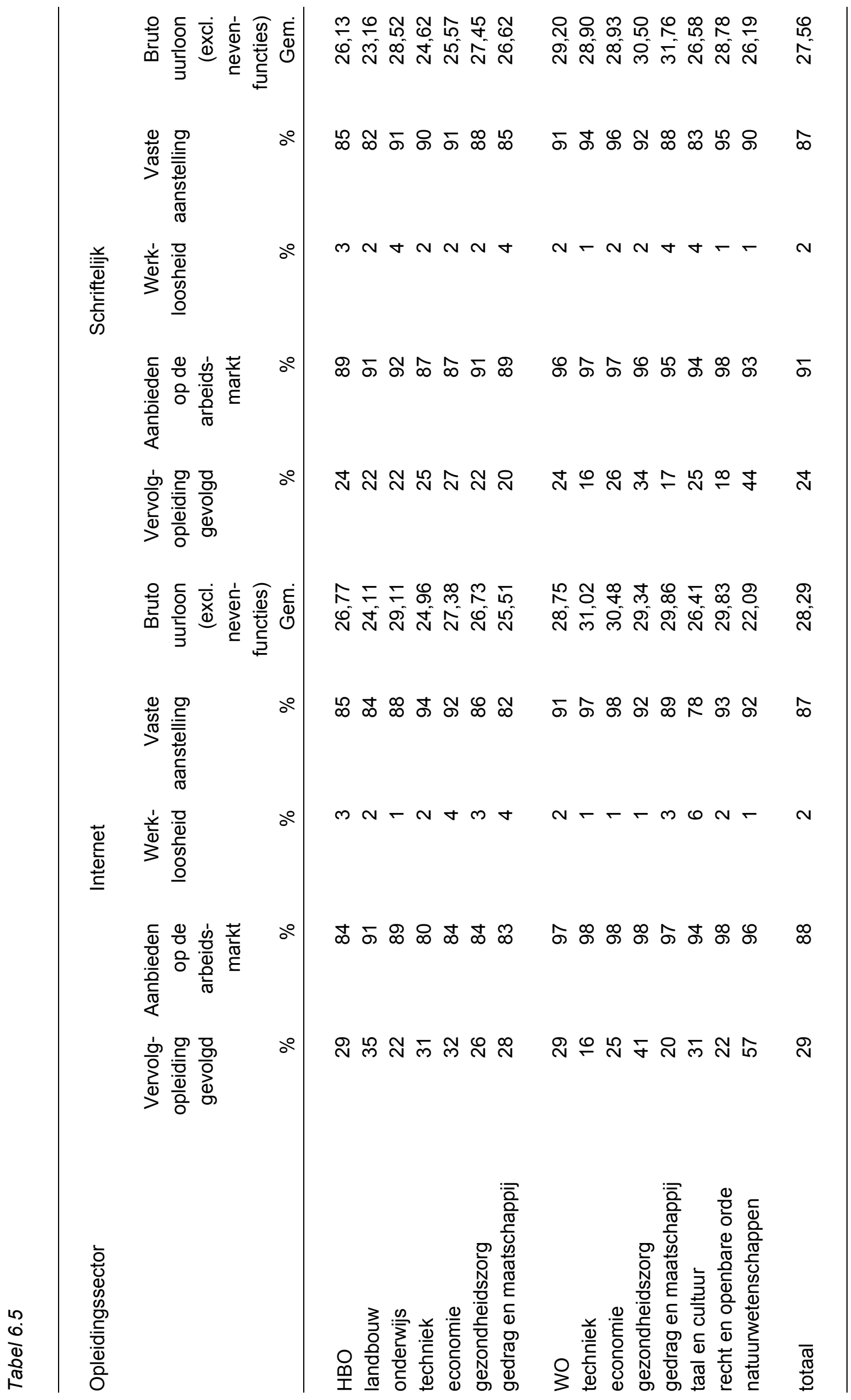


Zoals ook al uit tabel 6.4 blijkt leidt de internetmogelijkheid er waarschijnlijk toe dat respondenten met een vervolgopleiding vaker via internet reageren en respondenten die zich aanbieden op de arbeidsmarkt minder vaak via internet reageren. Dit laatste kan leiden tot een verdere ondervertegenwoordiging van het aantal respondenten met betaald werk (zie ook paragraaf 5). We zien echter dat deze ondervertegenwoordiging niet leidt tot verschillen in de arbeidsmarktpositie van schoolverlaters tussen beide responsgroepen.

\section{Besluit}

In dit werkdocument is de methodiek beschreven van het Schoolverlaters Informatiesysteem (SIS) dat door het ROA in 2000 is uitgevoerd. Naast een overzicht van de opzet van dit onderzoek, de gehanteerde classificaties en de uitgevoerde controles en toegepaste correcties op het databestand, is vooral ingegaan op de dekkingsgraad, de respons en op het non-responsonderzoek. Verder is ook nog uitvoerig ingegaan op het verschil tussen de afgestudeerden die de vragenlijst via internet hebben ingevuld en de afgestudeerden die vragenlijst schriftelijk hebben ingevuld.

Uit het gepresenteerde overzicht van de dekkingsgraad blijkt dat het schoolverlatersonderzoek over het algemeen zeer grootschalig van opzet is. Alleen in het AVO en het VBO is er sprake van een lage dekkingsgraad (respectievelijk $8 \%$ en $9 \%$ ).

Ten opzichte van de voorgaande jaren is er een dalende tendens te zien in de responspercentages. Het AVO scoort met $47 \%$ het best (in 1999 was dit $53 \%$ en in 1998 was dit zelfs nog 60\%), op de voet gevolgd door BOL niveau 3/4 en het WO (beide 46\%). De respons binnen BBL niveau $1 / 2$ is het laagst $(28 \%)$. Als naar regio wordt gekeken blijkt dat schoolverlaters uit de regio west het slechtst responderen. Een belangrijke vraag is verder of de (non-)respons selectief is. Dit blijkt enigszins het geval te zijn. Toch kan geconcludeerd worden dat het uitgevoerde onderzoek een redelijk betrouwbaar beeld geeft van de bestemming en arbeidsmarktpositie van schoolverlaters. In een poging om inzicht te krijgen in de redenen van deze daling, is voor het meetjaar 2001 het non-responsonderzoek inhoudelijk aangepast. Ook is de steekproefomvang van het onderzoek verdubbeld. verder zijn de begeleidingsbrieven bij de vragenlijsten uitgebreid met gepubliceerde informatie over de desbetreffende opleidingen.

In 2000 is de mogelijkheid geïntroduceerd om de vragenlijst via internet in te vullen. Van de schoolverlaters van het AVO en de afgestudeerden van het $\mathrm{HBO}$ en WO heeft $42 \%$ de mogelijkheid gehad de vragenlijst via internet in te vullen; daarvan heeft $27 \%$ daadwerkelijk via internet gereageerd. De afgestudeerden van de sector WO natuurwetenschappen reageren het vaakst via internet $(41 \%)$ en de afgestudeerden van de sector HBO onderwijs reageren het minst vaak via internet (19\%). De vraag is vervolgens of de mogelijkheid tot het invullen van de vragenlijst via internet gevolgen heeft voor de samenstelling van de respons(-groep). Uit de uitgevoerde analyse blijkt dat mannen en allochtonen oververtegenwoordigd zijn in de internetgroep. Dit is een gunstig, want de respons onder mannen en allochtonen is over het algemeen lager dan onder vrouwen en autochtonen. Verder zijn betaald werkenden ondervertegenwoordigd in de groep van internetrespondenten. Deze ondervertegenwoordiging 
leidt er overigens niet toe dat de arbeidsmarktpositie van de betaald werkenden die de vragenlijst via internet hebben ingevuld afwijkt van degenen die de vragenlijst schriftelijk hebben ingevuld.

\section{Literatuur}

Willems, E.J.T.A. \& A.S.R. van der Linden (1998), Methodiek schoolverlatersinformatiesysteem 1996, ROA-W-1998/1, Maastricht.

Tribe, J. (1996), Core Skills: a Critical Examintion, in: Educational Review, 48 (1), pp.13-27.

Genugten, B.B. van der (1986), Inleiding tot de waarschijnlijkheidsrekening en mathematische Statistiek deel 1, Stenfert Kroese, Leiden-Antwerpen. 



\section{Appendix A: Kernvragenlijst}

Tabel A.1

Overzicht kernvragen Schoolverlatersinformatiesysteem

Variabele

Opmerking

\author{
algemeen \\ geslacht \\ leeftijd \\ allochtoon \\ toestemming doorgeven gegevens aan school

\section{onderwijsloopbaan} \\ gevolgde opleiding \\ voltijd- of deeltijdvariant van gevolgde opleiding \\ begindatum gevolgde opleiding \\ einddatum gevolgde opleiding \\ diploma of certificaat behaald van gevolgde opleiding \\ opnieuw kiezen van gevolgde opleiding \\ hoogste vooropleiding \\ vooropleiding voor hoogste vooropleiding \\ vervolgopleiding \\ voltijd- of deeltijdvariant van vervolgopleiding \\ vervolgopleiding diploma/gestopt \\ plaats van vervolgopleiding \\ aansluiting vervolgopleiding op gevolgde opleiding \\ cursus/bedrijfsopleiding \\ cursus/bedrijfsopleiding totale duur \\ cursus/bedrijfsopleiding aantal uren per week
}

arbeidsmarktintrede

maatschappelijke positie sinds schoolverlaten

actief gezocht naar werk tijdens of na opleiding

begin actief zoeken naar werk

betaald werk gewenst aantal uren

betaald werk laatste 4 weken gezocht

beschikbaar betaald werk

reden niet beschikbaar voor betaald werk

inschrijving arbeidsbureau

huidige functie begindatum

huidige functie werving

huidige functie beroep SBC '92

huidige functie branche SBI ' 93

huidige functie personeelsomvang bedrijf

huidige functie vestigingsplaats bedrijf

huidige functie dienstverband

huidige functie aanstelling

huidige functie vereist opleidingsniveau volgens werkgever

huidige functie vereist opleidingsniveau volgens schoolverlaters

huidige functie vereiste opleidingsrichting volgens werkgever

huidige functie vereiste opleidingsrichting volgens schoolverlater

huidige functie leidinggeven

huidige functie arbeidsuren per week

huidige functie bruto maandinkomen

huidige functie aansluiting met gevolgde opleiding
$\mathrm{HBO} / \mathrm{WO}$

niet IVBO wel MBO/HBO/WO

MBO (beperkt)/HBO/WO

$\mathrm{MBO} / \mathrm{HBO} / \mathrm{WO}$

$\mathrm{HBO} / \mathrm{WO}$

$\mathrm{HBO} / \mathrm{WO}$

AVO/MBO

niet WO

niet voor AVO

$\mathrm{MBO} / \mathrm{HBO} / \mathrm{WO}$

$\mathrm{MBO} / \mathrm{HBO} / \mathrm{WO}$

MBO/HBO/WO

bij kunst zowel betaalde als onbetaalde werkkringen

$\mathrm{MBO} / \mathrm{HBO} / \mathrm{WO}$

niet IVBO/(I)VBO groen en VAVO

niet AVO wel MBO/HBO

HAO en WO LUW

niet bij AVO

HAO en WO LUW

MBO (beperkt)/HBO/WO 
Tabel A. 1 (vervolg)

Overzicht kernvragen Schoolverlatersinformatiesysteem

Variabele

Opmerking

nevenfuncties

$\mathrm{MBO} / \mathrm{HBO} / \mathrm{WO}$

nevenfuncties aantal uren per week

opleiding-huidige functie: belang van kennis en technieken

$\mathrm{MBO} / \mathrm{HBO} / \mathrm{WO}$

opleiding-huidige functie: belang van vaardigheden

$\mathrm{MBO}$ (beperkt)/HBO/WO

opleiding-huidige functie: belang van houdingsaspecten

MBO (beperkt)/HBO/WO

opleiding-huidige functie: belang van houdingsaspecten

MBO (beperkt)/HBO/WO

opleiding-huidige functie: aandacht voor kennis en technieken

$\mathrm{MBO}$ (beperkt)/HBO/WO

opleiding-huidige functie: aandacht voor vaardigheden

$\mathrm{MBO}$ (beperkt)/HBO/WO

opleiding-huidige functie: aandacht voor houdingsaspecten

MBO (beperkt)/HBO/WO 